\title{
Challenges in Implementing Inclusive Development Concept in Sustainable Development Goals 2030
}

\author{
Nurul Hidayat Ab Rahman \\ SAIDATUl Nadia AbD AzIZ
}

\begin{abstract}
The United Nations (UN) has undertaken several international efforts known as the sustainable development plan to preserve the right of development for future generations. This article presents a summary of the previous Millennium Development Goals 2015 (MDGs) that failed to include all people in the sustainability agenda, especially the vulnerable ones. As this situation has widened the society's gap, the new Sustainable Development Goals 2030 (SDGs 2030) aims to incorporate the concept of inclusiveness in the current development work. This article aims to highlight the challenges to materialize a successful inclusion in the SDGs 2030. It should be explored in more detail to ensure that it can be adequately addressed for the plan to succeed. This writing is based on a pure legal research framework using qualitative methods. Data were collected through library studies and analyzed critically using content analysis method. This paper identifies that stigma and discrimination, special privileges and lack of data are among the barriers in implementing the concept of inclusivity in the SDGs 2030. Therefore, the paper proposes that laws and policy must be established to support this cause. Besides that, the privileges granted must be balanced with assistance to the vulnerable people in order to achieve equality. As for data collection, countries all around the world must work hand in hand to continue making efforts in gathering comprehensive data of the vulnerable groups.
\end{abstract}

Keywords: Inclusive development; millennium development goals; sustainable development goals; discrimination; development law

\section{INTRODUCTION}

'Development' has been defined as an inalienable human right that aims to advance human life through free and meaningful participation in economic, social, cultural and political aspects. It is also a situation that involves the growth of a product, idea or event. It is related to positive changes even though the question of who will determine whether a change is good or not is vague. ${ }^{1}$ Rawls suggested that, through development, opportunities for fairness in the distribution of goods and services such as food, shelter, education, health, protection, and others will increase. This situation indirectly allows people regardless of social class to gain access to public facilities and services. Besides that, human life can be improved in many aspects, namely social, political and economic. People will have choices and opportunities which help to raise their living standards to be conducive and prosperous. Ultimately, human dignity will be more valued as the life standards of the vulnerable people will be elevated. As the term continuously viewed as something advantageous in improving various dimensions of human life, the responsibility to ensure optimum success of the development is divided among the world community. ${ }^{2}$

Through time, an extended concept of development called 'sustainable development' is created in the Bruntland Report 1987. ${ }^{3}$ It is defined as a development that meets the needs of the present without compromising the ability of future generations to meet their own needs. 'Sustainability' in simplest words meant to prolong the period of human life by integrating development with the three main facets namely social, economy and environment. Therefore, sustainable development early emergence is rooted out from human's wish to preserve natural resources and the harmony of the earth for their children. Correspondingly, people also want to guarantee that there is no exclusion of any social group in receiving the benefits of development as it will only worsen the massive society gap that already existed. Therefore, the UN in order to encourage the involvement of all societies' members in the development process, implements the concept of inclusiveness as the primary key in the SDGs 2030.

From this explanation, it is clear how sustainable development concept has it links with 
inclusivity principle, as it emphasizes not only on the present people achievements, but it must also contemplate the benefits for posterity. Other than that, socio-economic gaps that existed in this world must be close in order to materialize sustainability. It entails every human partaking without anyone forsaken. However, the idea to implant the concept of inclusive development in the SDGs 2030 is ambitious. Thus the challenges need to be discussed thoroughly as it will help to lead humans in achieving the final goal of sustainability.

\section{INCLUSIVE DEVELOPMENT AS HUMAN RIGHTS}

The first Human Development Report in 1990 introduced the Human Development Index that based development not only on economic achievement but includes other indicators such as life span, literacy and use of resources to enjoy a good life. ${ }^{4}$ These indicators are the fundamental rights of human ${ }^{5}$ combined in one comprehensive term called 'development'. Hence, it is only accurate for development to be considered as one of the human rights belongs to everyone regardless of their identities. This right contains the entitlements to participate, contribute and enjoy all social, economic, cultural and political aspects. As the human becomes the central subject of development; not only will they contribute but benefits from it equally. Thus, all States have the responsibilities to formulate appropriate national development policies that will improve the well-being of its citizens. ${ }^{6}$ Henceforth, all States must focus on its people development by allowing them to actively participate and contribute in society. Other than that, they are also entitled to receive fair benefits of development. In addition, Article 5 and 6 of the UN Declaration of Development of Humans Rights required states to eliminate all forms of discrimination ${ }^{7}$ in rights to development such as racial, occupation and nationality. No distinction should be allowed on race, sex, and language or religion basis in implementing all civil, political, economic, social and cultural rights. ${ }^{8}$ It is to be highlighted that although the UN Declarations are not legally binding, it plays a vital role not only in establishing international legal norms, but also guiding the UN States Parties to particular directions and abiding by certain standards, Some of its provisions also are embedded in legally binding instruments such as Charter of the United Nations, International Covenants on Human Rights, states statutes or accepted as part of customary international law.

On the other hand, "social exclusion" is a contradiction to the concept of inclusive development. It is describes a situation in which disadvantaged groups of individuals are unable to contribute in economic, social, political and cultural life. The conflict of social exclusion occurs everywhere in the world and not only limited to poverty but linked to numerous reasons such as ages, genders, races, ethnicities, religions and more. It involves marginalization or dismissal of particular human groups in achieving targets for development purposes. As a consequence, efforts to safeguard the partaking of all human groups in the development processes will become complicated. It is related to many issues such as personal data collection, judgmental society, lack access to economic resources and many others. In addition to that, vulnerable groups of people also are incapable to participate as they human rights and dignity are not accorded to equal respect and protection. Hence, apart from material deficiency social exclusion also occurs due to abandonment of the weakest groups in world hierarchy in every aspects of life. The previous global agendas, namely, the Agenda 21 in $1992^{9}$ and the MDGs in 2000 had promoted the importance of inclusivity in the development process. Referring to different kinds of researches and Human Development Report 2014, it is concluded that the increase of inequality is among one of the major factors that cause deterioration of the development process. Henceforth, the current SDGs 2030 emphasized on the importance of the inclusivity concept to be instilled in the whole agenda.

\section{LESSON LEARNT FROM MILLENNIUM DEVELOPMENT GOALS 2015}

Since the MDGs's commencement, sustainable development is recognized as the global agenda for countries to reform the existing way of life and administration for the survival of future generations. Ended in 2015, MDG was concluded as a successful agenda that brought many enhancements in various aspects of life..$^{10}$ However, the UN official report summarized that the agenda failed to consider effective methods to implement the plan for the poor and vulnerable. There are 
millions of people who are less fortunate in terms of finance, gender, age, ability, ethnicity and even geography to drop out of this development agenda. The marginalized community could not get any positive impact from the plan, and this has led to a wide disparity in the development progress. The World Development Report stated that none of the low-income or in conflict countries could achieve even one from eight goals set up in the MDGs. Both poor and populous countries such as the continents of Africa, China, India and Indonesia face greater challenges in achieving MDGs' goals as compared to the European countries with stable economies and advanced technologies. ${ }^{11}$

As the world do not fully achieve the targets of the MDGs and there are a lot more to be done, loopholes or weaknesses of the previous agenda need to be studied in-depth and refined to improvise the implementation of the latest sustainable plan. Based on the previous experience and data analysis, the SDGs 2030 must be carried out more prudently. Consequently, the integration of economic, social and environmental dimensions is crucial to address any issues identified. Other than that, involvement and commitment of all parties to eradicate extreme poverty is a key to guarantee that "no one is left behind 'and a just, equitable world development can be achieved.

\section{INCLUSIVE DEVELOPMENT IN SUSTAINABLE DEVELOPMENT GOALS 2030: A NEW HOPE}

The overall objective of the SDGs 2030 includes three-dimensional integration of social, economic and environmental aspects. It indirectly promotes a development that integrates the essential facets of life for both present and future generations. Henceforward, it requires a more holistic, flexible and integrated approach at all levels, national, regional and global. There are many ways to stimulate community participation in the development process, which among others are the emphasis on one's ability and also potential encouragement. The ability or the potential to voice an opinion to the public is one of the criteria for social inclusion. This power might affect the policy choice of government in many matters such as housing, labour markets, health care and many others. On the other hand, other writers focus on the politics of governance that underlies cooperation between institutions ${ }^{12}$ and redistribution of power. Through social inclusion, the importance of social justice can be improved through the existence of dialogue among community members. For example, inter-religious or educational dialogue can pave the way for social inclusion. This situation will not only open the door for members of the community to understand one another but cultivate respect and promote unity. Furthermore, social inclusion is expected to be efficient if it is formulated as a target in a long-term scheduled plan. Other than that, it should also involve young people's opinions on issues that are closely related to their future to encourage intervention. By including all sectors of society, it will provide better hope and motivation in developing a prosperous, sustainable nation. Lastly, sports programs, cultural celebrations and even social media can be among of the best ways to address social differences and encourage community involvement.

Several indications in the SDGs 2030 reflect the enthusiasm of the agenda to ensure that all people are able to participate in sustainable development goals, or in other words, without discrimination or social exclusion. Firstly, the SDGs 2030 was developed with the theme of, 'Transformation of the World' with comprehensive and interconnected five facets, which are, "People, Planet, Poverty, Peace and Partnerships" (UN). All of these essentials are complex and require the approach of various stakeholders such as government bodies, private bodies and the general public. Through the participation of a diverse group of people from different backgrounds in 193 countries, the SDGs 2030 is expected to meet the aspirations of social inclusion.

Moreover, the term 'inclusiveness' is stated 27 times in the entire SDGs 2030 document, while 'no one is left behind' are used five times. Other metaphors such as 'disabled' and 'vulnerable' are mentioned 11 and six times, respectively. The frequency of these mentioned terms had demonstrated the dedication of the SDGs 2030 to revise the earlier MDGs that exclude disadvantaged or vulnerable human groups. Besides that, the elements of social inclusion also reflected through the recognition of children as one of the agents of change in the SDGs 2030. "Agent of change" means a person with skills and authority to stimulate, facilitate and coordinate the efforts made during the change. Successful changes depend on the quality of the relationship between the agents of change with the decision-makers in a particular organization. ${ }^{13}$ 
Among others, the UN has setup SDG 16 as a specific goal in achieving social inclusion of all community members. Specifically, the sixteenth target is aimed at promoting social security and inclusion of every member in society for sustainable development and providing access to justice through the establishment of effective, responsible and comprehensive institutions at all levels. SDG 16 aims to provide legal identity to all through birth registration. Legal identity is frequently defined as a one of human rights, yet in reality it works as precondition before other fundamental human rights such as education, health care and social welfare benefits can be accessed. In order to claim benefits provided by states for example, often documentation that proof one's identity is required. Looking at the implications of legal identity for the achievement of other SDGs, the UN had made 'legal identity' as an essential cross-cutting goal in the SDGs 2030. It is believed that to hold on such rights is one of the ultimate guarantees to improve development outcomes. Besides that, it seeks to end all forms of abuse, exploitation, trafficking and violence as well as torture of children, encourage participation, abolish discriminatory laws and policies and many more. In order to successfully implement the ambitious SDGs 2030, it will necessitate enormous amount of global investment in infrastructure of various sectors, such as environment, health, education, peace, security and many others. Thus, SDG 17 comes in hand where the goal supports the element of social inclusion as its objectives are to strengthen the implementation and renewal of Global Partnerships for Sustainable Development Goals. ${ }^{14}$

Transforming the social, cultural, political and institutional norms is indeed a challenging task that works as well as an opportunity. However, it is possible to overcome the hardships with the encouragement of the governing government. Even though inequality is not rising everywhere in the world, the level is still high within countries. Income inequality especially has increased in most developed country, and absolute income differences keep growing between countries. The world is far away from reaching the ultimate objective; leaving no one behind by creating equal opportunity for all human beings. Group-based inequalities based on factors such as socioeconomic, gender, race, ethnicity and many others continue to rise globally. ${ }^{15}$ Hence, the Governments need to confront the root causes of social exclusion and guarantee that all the people around the world enjoy the benefits of development. Only by doing this, sustainable development can be attained for everyone. Besides that, social inclusion helps to keep the world from oppressing the fundamental rights of vulnerable people due to the disadvantages they face. Society needs to protect the human rights documented at both national and international levels to build a world that is fair, just and comfortable for all to live in.

\section{CHALLENGES IN IMPLEMENTING INCLUSIVE DEVELOPMENT}

\section{STIGMA AND DISCRIMINATION}

Many studies explained the grounds of social exclusion that existed based on a combination of different problems such as unemployment, lack of skills, low income, incomplete housing facility, high crime rates, poor health status and many others. Social exclusion may occur to anyone, but the characters and social environments of vulnerable groups will further increase the risk of such phenomenon. This is because the internal stigma of society has caused continuous discrimination towards particular groups of people that apparently develops prejudice towards them. The unfortunate people will be treated unevenly in numerous functions as they may be influenced by identities factors. There are two types of identities in society; one is a human group that recognizes such membership, shares the same life values, and collaborates. This kind of group commonly depends on identities such as caste, ethnicity and religion. The second category is built on shared features and ways of living. They do not necessarily know each other or have much in common, but the cause of the discriminations they face is the same. Some examples of this group are street children, people with HIV/AIDS, illegal immigrants and others.

Social exclusion is also happening due to climate change, demography and globalization. The World Meteorological Organization reported that the number of dangers arising from the drought, high temperatures, floods and storms had risen dramatically worldwide. These natural disasters will leave massive shock on the affected groups, especially the vulnerable ones. As a result, they will become weaker, and their status in 
society will be jeopardized. For instance, a group of people who lives in the area with ineffective environmental management due to the lack of budget or the heavy use natural resources for industrial purposes.

Other sources of social exclusion are economic growth, high income and social mobility or known as urbanization. The urban populations always have better access to education, health care and other essential services as compared to the one in rural areas. This fact alone can contribute to the social exclusion of the rural community, as it is not likely for them to enjoy all the facilities and opportunities such as those living in the city. Every aspect of their lifestyle is more mundane in terms of quality and quantity. Moreover, financial income is the main point that causes a gap in the social status of society members. Urban communities enjoy the most excellent facilities and finest services provided in the town as compared to those staying in rural areas. In line with the process of urbanization, the fertility rate is declining each year while the human lifespan is raised. This condition led to a growing number of elderlies as compared to the birth of babies in the world. It is feared that this situation will later affect the continuity of national development since it is monopolized by certain group age of people. It is merely means that the social protection system is turning weaker as the continuity of young generations is affected.

Finally, the trend of people all over the world migrating either voluntarily or forced, to certain countries had become one of the factors of social exclusion. This is because the preferred countries are forced to receive foreign immigrants to live with local citizens. Over the past few years, the citizens of the receiving countries are no longer celebrating the arrival of refugees or migrants; in fact, the situation is considered as one of the dangerous threats to the country. For that purpose, a number of requirements and rules are set and need to be fulfilled by foreigners as the policy for each country to receive foreign immigrants varies. As examples, there are specific procedures in employment, acquisition, citizenship and others that involved migrants. Most states also have chosen to tighten their immigration policies to prevent the influx of immigrants. However, such a measure cannot prevent migration from occurring but lead to a more critical social exclusion of foreign migrants. Such condition will affect their socio-economic stability, and they usually end up as forced labor who suffered exploitation and limited life margin in the society. The same situation applies to asylum seekers as well as refugees.

Thus, SDGs 2030 pledged to 'leave no one behind' and 'endeavor to reach the furthest first'. In order to uphold these aspirations, there are three primary keys highlighted in the new agenda. First is to identify the vulnerable ones and get their data; secondly is to enabling their voice by allowing participation and lastly to enact inclusivity in strategies planned. SDG 10 prioritizes the aim of reducing inequality within among countries by lifting people out of poverty, inequalities and large disparities remain in income and wealth and also in access to other assets and essential resources to achieve full dignified life. Four of the ten targets within SDG 10 address within country inequality across social, economic and political dimensions. The purposes are to expand prosperity, inclusion, and social protection. The other three goals, determines to reduce inequality among people and countries. The last three objectives focus on the means of effective implementation and distributing resource to the most vulnerable groups.

\section{PRIVILEGES}

The attitudes or behaviors of community members, as well as institutional policies also contribute to social exclusion for particular human groups. Even though the participation of every society member is encouraged in the previous sustainable development agendas, it can only be materialized with a supportive setting. In specific condition, the surrounding layouts have acted systematically to repudiate the rights of several groups of people to join the community at full force. For example, non-registered children do not get access to services such as health or education because of bureaucracy setup. Facilities like special school for disabled children were located only at big cities, and some children living in remote areas do not even get a chance to enjoy education rights.

Most importantly, the law or rule making institution should set aside any elements that will lead to social exclusion or at least finding alternatives to minimize such impact. ${ }^{16}$ In many nations and cultures, there are prerequisites listed in statutes, regulations or policies, involving 
elements such as race, ethnic, citizenship status and others that will segregate types of human groups. Specific groups profited and thrived because of the entitlements or privileges granted solely as a birthright. It is not linked to one's talent or capacity. There are five core components agreed by many authors that define privilege. First, it is not something common, general or universal but a special advantage. These advantages were granted upon them by society neither because of their ability nor intelligence. Besides that, privilege is related to a preferred status or rank. It will benefit the recipients but at the same time become the exclusion or detriment to others. Finally, a person possessing privileged status is often unaware of its existences. These types of laws are giving special treatment to few groups of human beings. It will not only stave off the efforts by disadvantaged groups to advance their life quality but indirectly failed the mission to reduce the gaps between community members. In short, the social norms and the essence of institutional policies can influence the involvement of marginalized people into civilization.

As an illustration, the aim of MDG 8 is to build a global partnership for development purpose. This goal is essential to boost the spirits of cooperation among countries in order for the world to accomplish sustainable development. However, it had received lots of criticism since the goal only focuses on the commitment of developed countries. For instances, successes of certain MDGs goals are not distinguished as achievements of MDG activities, but by-product of the rapid economic growth of certain high-income countries. Some writers considered the goal set as a sort of isolation of underdeveloped countries, obscure, quantitative and inadequate. It is because the targets to develop a more open, regulatory, predictable and non-discriminatory trading and financial system are unachievable. It has also been critiqued as an unclear objective with the unambiguous method that provides no quantitative benchmarks in specific periods.

It can be concluded that social exclusion or discrimination may be due to consent by the government to enact special provisions in legislation to safeguard the interests of particular groups of people. Consequently, colonial power becomes bound by the law that sets the status, hierarchy or privilege of a specific ethnic group and race. This situation will later on sparks displeasure among the ignored members of the society and create the spirit of racial and prejudice. Slavery is one of the classic examples that represent the issue of extreme social exclusion. Those who become slaves are considered as property, and in most situation, they lose their freedoms, such as the right to have a family. Slavery often occurs in the context of war and is heavily influenced by factors such as religion, race, ethnic minority, society, custom, gender and origin. In this modern world, social exclusion still exists through slavery, such as child labor and sex trafficking. Malaysia does not prohibit children from working but regulate through a specific legal statute. ${ }^{17}$ The children are allowed to work with several conditions, and there are some provisions drafted to protect them. However, the regulation has limited application excluding migrants and people with disabilities and others. It becomes common that those who are easily affected usually been neglected by state and community.

Michalopoulos and Papaioannou illustrate arbitrary Western powers created the division of national boundaries in Africa that serving different ethnic groups as an example of social exclusion. Besides, the legal systems such as Apartheid in South Africa are one of the results of colonization that has destroyed the indigenous people of the world in the face of mass discrimination and atrocities against the black society. ${ }^{18}$ These examples show that social exclusion is not merely a matter of one's conduct, however widespread, but should be thought of primarily as a systemic issue of collective, and in particular of state, responsibility. Such responsibility is often related to the idea of a 'debt' owed to minorities that have suffered official legally entrenched discrimination or unfavorable treatment inflicted or sanctioned by the state. Those historical practices have produced a situation for which society and the state are accountable.

Thus, the SDGs 2030 has emphasized that it is vital for every community member to cooperate in development issues regardless of their differentiation. The community especially those in power need to be more sensitive of the vulnerable people's needs and play significant roles in assuring that impoverished people have the prospect to engage in social interactions, power 
of distribution, status and control over resources. Laws and regulations legislated must protect all human rights equally to close the existing social gaps.

\section{LACK OF DATA}

Measuring a discrimination level is crucial in order to determine the seriousness of the problem in a particular area. It is a challenging task to measure a level of social exclusion as it is multidimensional and lack of data collection on vulnerable groups across the country. Furthermore, it is also essential for people to be able to identify what can be regarded as discrimination. This is because there are many ways for one to be discriminated. It might comprise more than just direct conduct but includes subtle and unconscious actions like posture or tone of voice. Discrimination against an individual may be based on overall assumptions about members of a disadvantaged racial group that are assumed to apply to that individual, for example, statistical discrimination or profiling. Discrimination may also occur as the result of institutional procedures rather than individual behaviors.

Based on the limited existing data, analysis can still be performed to get the general ideas on the factor of social exclusion. Social exclusion is a word widely used to refer to phenomena related to poverty, deprivation and hardship. These conditions have a long history in leading the vulnerable people to inequity and oppression; which later subject them to countless unfortunate situations such as mental and physical disabilities, suicide, child abuse, drug addicts, neglected single parents and many more. It merely shows that identity differences, public acceptance, legal provisions, urbanization and migration are among causes of discrimination. Through the above explanation, social exclusion occurs on multiple reasons depending on context and time. Individuals of the affected groups only owned limited access to life resources, including income, land and housing. It is also includes services such as education and health care that are essential for living and survival purposes. Therefore, 17 goals enlisted in the SDGs 2030 is meant to provide aid to the vulnerable in a different life aspects. ${ }^{19}$

Without a single standard method that is applicable for all at a national or international level, it is challenging to measure discrimination. It makes recovery from this issue becomes more difficult and complicated. As an example, the social exclusion of street children has existed for many years and still risen until now to a very alarming level. The estimated number of street children worldwide in 1989 was 100 million, and five years later the UNICEF still reported the same figure. The estimations are considered baseless as the world population rise over the years, but the number of street children has remained unchanged; although this issue is still failing to find practical solutions. In 2004, there was a literature estimate at least the rise of 150 million street children, and the number is likely that the number is even higher, reaching 10 million. Apparently, the inconsistency of data collected among others is because the unavailability of a method to value discrimination.

Thus, the SDGs 2030 aimed at incorporating inclusive development considered data on the nature, impact and amount of discrimination that has occurred in connection with the implementation of the past MDGs. This is because it is the only way to prevent such things from happening again and at the same time, implement the current sustainable development projected. However, the 2019 report stated that most countries do not frequently accumulate data for more than half of the universal indicators. The nonexistence of precise data on many marginalized groups makes them undetectable and, this condition will worsen their state of vulnerability. The report further admitted that only limited progress had been made in terms of data collection for four years of the SDGs 2030 implementation. Therefore, investment in data collection is encouraged in order to fulfill the agenda. The Dubai Declaration ${ }^{20}$ that promotes countries to increase financing for better data and statistics for sustainable development was launched. For examples, broadband infrastructure, appropriate policy and strategy need to be developed, as well as reliable and secure telecommunication networks. Beyond funding, the Declaration also calls for political, technical and advocacy support in all areas. As illustration, a project known as Data-Pop had been developed jointly by Harvard Humanitarian Initiative, the MIT media Lab and Overseas Development Institute. The project is a collaborative efforts to:- (i) diagnose local realties and human problems with data; (ii) mobilize capacities, communities, and ideas towards more data literate societies; and (iii) transform the systems and process that underpin societies and countries. In addition to that, policy-makers and 
regulators also plays a part to ensure fair, transparent, stable and non-discriminatory enabling policy and legal provisions. ${ }^{21}$ Developing mechanisms to collect data are indeed continuous works that must be done from time to time in order to achieve updated figures using efficient methods.

\section{CONCLUSION}

Incorporating the concept of inclusion in the SDGs 2030 is an essential component for the world to achieve successful sustainable development and to ensure that the history of past sustainable development failures (MDGs) is not repeated. By accentuating this concept in the current plan, it will direct countries all over the world to pay close attention on the importance of inclusivity and make some adjustments to current administration. For example, fair budget distribution, built data collection system, strengthening institutions, amends legal provisions and others. This is because it is crucial to safeguard the legal rights owned by everyone without any exceptions. Furthermore, the opportunity of the future of generation to develop in all aspects of life can be preserved, including human survival in general.

However, through experience, we should have learned that development rights can only be achieved by integrating all classes of society without discrimination. The neglect of certain groups, especially vulnerable people will interrupt the development plan, and failed the entire agenda planned. The underdeveloped groups of people in any countries will slow down the world development progress as a socioeconomic gap keeps widening. The economic difference will have an impact on their social life as well as the environment. In the long run, the conditions of the left out-group will stifle the development of the world as a whole. While there are groups of nations or societies that are continually pursuing progress, they will not be at their maximum. As such, the SDGs 2030 is the only medium that best to provide an opportunity for the next generation to live in the future. This sustainable development plan, among other things, emphasizes the need for inclusive concepts to prevent discrimination against any party. However, the existing settings in today's life will pose challenges to the concept of inclusiveness. The challenges identified are stigma and discrimination, privilege and lack of data for the vulnerable.
Stigma and racial discrimination are based on long-standing ideas or opinions that have been embedded in people's minds for so long, thus it is difficult to be recuperated. Five key factors that cause stigma are discrimination, geography, shocks and fragility, socio-economic status and governance. However, the world cannot give up on changing the perception of society to the disadvantaged. Through SDGs 2030, every opportunity to reintegrate their roles into society must be utilized. Existing rules and regulations should regulate matters related to privileges. The possible impacts must be considered before any privilege is enacted. For example, the granting of privileges should be balanced with regular and ongoing assistance to the vulnerable with the objective of removing them from the challenges of life. Such a situation will reflect the concern and responsibility of a government to ensure that its administration does not oppress any party and is fair. Furthermore, it will contribute to the efficiency of the SDGs 2030.

The data or information on the vulnerable is extremely difficult to identify because they are not registered and live in different areas of the common community. Moreover, nomadic lives, as well as the absence of definitions will make them invisible to the public. Therefore, the SDGs 2030 continuously encourages all efforts and investments made by countries around the world to gather complete and up-to-date data on the status of vulnerable groups. It is because data is an important key to the concept of inclusiveness. It will reveals the level of social exclusion and later allowing measure to be taken in response where possible. At the same time, laws at both international and national level coupled with policy of all institutions must be established to support social inclusion. For that, reference to the SDGs 2030 plan must be made as the targets will address the issue of discrimination to fulfill its mission in sustaining development as best as possible.

\section{NOTES}

Article 1 of Declaration on the Right to Development.

United Nations. Declaration on the Right to Development, available from, https://www.ohchr.org/EN/ ProfessionalInterest/Pages/RightToDevelopment.aspx Accessed on: 15th December 2019).

3 Federal Office for Spatial Development ARE. 1987. Brundtland Report, available from, https://www.are.admin. $\mathrm{ch} / \mathrm{are} / \mathrm{en} / \mathrm{home} / \mathrm{sustainable-development/international-}$ cooperation/2030agenda/un-_-milestones-in-sustainable- 
development/1987--brundtland-report.html Accessed on: 15th December 2019).

4 United Nations Development Programme. Human Development Index (HDI), available from, http://hdr.undp. org/en/content/human-development-index-hdi Accessed on: 10th April 2020).

5 As example, rights to life, rights to education, the rights to equality and many others.

6 Article 2 of the UN Declaration on the Rights of Development

7 This principle has been enacted in various conventions such as the Convention on the Rights of the Disabled (CRPD), the Convention on the Elimination of All Forms of Discrimination against Women (CEDAW), the CRC and more.

8 Article 5 and Article 6 of the UN Declaration of Development of Humans Rights.

9 Agenda 21 is an action plan with regards to sustainable development that had been developed during United Nations Conference on Environment and Development known as 'Earth Summit' in 1992 at Rio de Jeneiro, Brazil.

10 UNDP. 2016. From the MDGs to the Sustainable Development for all, available from, https://www.undp.org/ content/dam/undp/library/SDGs/English/From the MDGs to SD4All.pdf Accessed on: 16th December 2019).

11 Millennium Development Goals Report. Latest Major Publications - United Nations Department of Economic and Social Affairs, 2015. available from, https://www.un. org/en/development/desa/publications/mdg-report-2015. html Accessed on: 15th December 2019).

12 Also known as democracy in decision-making.

13 Lunenburg, F. C. Managing change: The role of the change agent. (2010) 13 International Journal of Management, Business and Administration 1.

14 Gupta, J., \& Vegelin, C. Sustainable development goals and inclusive development. International environmental agreements: Politics, law and economics, 2016, 16:433.

15 The World Social Report 2020.

16 Kamal Halili Hassan. The Dismissal of a Pregnant Stewardess: Still Lawful in Malaysia. (2012) 21 Journal of Gender Studies 130.

17 Children and Young Persons (Employment) Act 1966.

18 Michalopoulos, S., \& Papaioannou, E. 'Divide and Rule or the Rule of the Divided? Evidence from Africa (No. w17184),' National Bureau of Economic Research, 2011.

19 For example SDG 1 for poverty, SDG 3 for health, SDG 4 for education and many others.

20 During the Second World Data Forum in October 2018.

${ }^{21}$ Dubai Declaration 2014.

\section{REFERENCES}

Abdullah, M. A., Basharat, Z., Lodhi, O., Wazir, M. H. K., Khan, H. T., Sattar, N. Y. \& Zahid, A. 2014. A qualitative exploration of Pakistan's street children, as a consequence of the poverty-disease cycle. Infectious Diseases of Poverty 3:11.

Abro, A. A. 2012. The Problems of Street Children: A Sociological Study of Urban Sindh, available from, http://eprints. hec. gov. pk/9360/1 Accessed on: 17th December 2019.

Adida, C. L. 2011, Too close for comfort? Immigrant exclusion in Africa. Comparative Political Studies 44:1370.
Alem, H. W. \& Laha, A. 2016, Livelihood of street children and the role of social intervention: Insights from literature using meta-analysis. Child Development Research.

Alkire, S. 2010. Human Development: Definitions, Critiques, and Related Concepts. SSRN Electronic Journal.

Ashwini, P. \& Singh, A. 2018, Social media for digital and social inclusion: Cultural, technological and economic implications. Asian Journal of Development Matters 12:159.

Attard, K. 2017. Sport and physical education: a tool for social inclusion, available from, https://www.um.edu.mt/library/ oar/handle/123456789/36897 Accessed on: 17th December 2019.

Basnett, Y., \& Bhattacharya, D. 2015. 'Exploring spaces for economic transformation in the Sustainable Development Goals,' London: Overseas Development Institute.

Bell, C. 2018. 'Political power-sharing and inclusion: Peace and Transition Processes,' Edinburgh: Political Settlements Research Programme.

Bhattacharya, D., Khan, T. I., Rezbana, U. S. \& Mostaque, L. 2016. 'Moving forward with the SDGs implementation challenges in developing countries.'

Burchardt, T., Le Grand, J., Piachaud, D., Hills, J. \& Grand, L. 2002. Understanding social exclusion, available from, https://gsdrc.org/document-library/understanding-socialexclusion-introduction/ Accessed on: 18th December 2019.

Chambers, R. 2004. Ideas for Development. Reflecting Forwards Working Paper 238 available from, http://citeseerx.ist.psu. edu/viewdoc/download?doi=10.1.1.487.8068\&rep=rep1\&t ype $=$ pdf Accessed on: 17th December 2019.

Curcic, S., Miskovic, A., Plaut, S. \& Ceobanu, C. 2014. Inclusion, integration or perpetual exclusion? a critical examination of the decade of Roma inclusion, 2005-2015. European Educational Research Journal 13:257.

Das, N. K. 2009. Identity politics and social exclusion in India's north-east: The case for redistributive justice. In The Politics of Social Exclusion in India 47.

Davey, S. \& Gordon, S. 2017. Definitions of social inclusion and social exclusion: the invisibility of mental illness and the social conditions of participation. International Journal of Culture and Mental Health 10:229.

Davis, T. W. 2011. The MDGs and the incomplete relationship between development and foreign aid. Journal of the Asia Pacific Economy 16:562.

Emas, R. 'The concept of sustainable development: definition and defining principles,' Brief for GSDR, 2015.

Fehling, M., Nelson, B. D. \& Venkatapuram, S. 2013. Limitations of the Millennium Development Goals: a literature review. Global Public Health 8:1109.

Gangadean, A. 2006. A planetary crisis of consciousness: From ego-based cultures to a sustainable global world. Kosmos: An Integral Approach to Global Awakening V 37.

Gehring, M. W., \& Segger, M. C. C. 2005. Sustainable development in world trade law, available from, https:// ciaj-icaj.ca/wp-content/uploads/documents/import/2006/ Gehring.pdf?id=1240\&1581946169 Accessed on: 10th April 2020.

Gidley, J., Hampson, G., Wheeler, L. \& Bereded-Samuel, E. 2010. Social inclusion: Context, theory and practice. The Australasian Journal of University-Community Engagement $5: 6$.

Gidley, J. 2005. Giving hope back to our young people: Creating a new spiritual mythology for Western culture. Journal of Future Studies 9:17. 
Gore, C. 2010. The MDG paradigm, productive capacities and the future of poverty reduction. IDS Bulletin 41:70.

Hayes, A., Gray, M. \& Edwards, B. 'Social inclusion: Origins, concepts and key themes,' Canberra: Social Inclusion Unit, Department of the Prime Minister and Cabinet, 2008.

Ianchovichina, E. \& Lundstorm, S. 2016. What is Inclusive Growth? Policy Research Working Paper 4851, available from, https://papers.ssrn.com/sol3/papers.cfm?abstract_ id=1410472 Accessed on: 10th April 2020.

Inglehart, R. \& Welzel, C. 2001. Foreword by Hans-Dieter Klingemann. Modernization, Cultural Change, and Democracy, available from, https://www.researchgate.net/ publication/230557603_Modernization_Cultural_Change and_Democracy_The_Human_Development_Sequence Accessed on: 20th April 2020.

Justino, P. \& Litchfield, J. A. 'Economic exclusion and discrimination: the experiences of minorities and indigenous peoples,' Minority rights group international, 2003.

Kabeer, N. 2015. Gender, poverty, and inequality: a brief history of feminist contributions in the field of international development. Gender \& Development 23:189.

Kabeer, N. 2005. Social exclusion: concepts, findings and implications for the MDGs. Paper commissioned as background for the Social Exclusion Policy Paper, Department for International Development (DFID), London, available from, https://gsdrc.org/document-library/socialexclusion-concepts-findings-and-implications-for-themdgs/ Accessed on: 20th April 2020.

Kabeer, N. 2005. Introduction: The search for inclusive citizenship: Meanings and expressions in an interconnected world, available from, https:/www.gov.uk/dfid-researchoutputs/the-search-for-inclusive-citizenship-meanings-andexpressions-in-an-interconnected-world Accessed on: 20th April 2020.

Kaye, M. \& McQuade, A, 2007. 'Poverty, Development and the Elimination of Slavery'

Labonté, R. N., Hadi, A. \& Kauffmann, X. E. 2012. 'Indicators of social exclusion and inclusion: A critical and comparative analysis of the literature,' Population Health Improvement Research Network,

Madheswaran, S. \& Singhari, S. 2016, Social exclusion and caste discrimination in public and private sectors in India: A decomposition analysis. The Indian Journal of Labour Economics 59:175.

Martine, G., Alves, J. E. D. \& Cavenaghi, S. 2003. 'Urbanization and fertility decline: cashing in on structural change,' International Institute for Environment and Development.

McInerney, C. 'Governance and partnership for social inclusion: Exploring the missing discourse Partnerships for Social Inclusion', Conference, Centre for Public Policy, Melbourne, 2008.

McIntosh, P. M. 1988. White privilege and male privilege: A personal account of coming to correspondences through work in women's studies available on https://www. wcwonline.org/Fact-Sheets-Briefs/white-privilege-andmale-privilege-a-personal-account-of-coming-to-seecorrespondences-through-work-in-women-s-studies-2 Accessed on: 18th December 2019.

Nanda, V. P. 2015. The journey from the millennium development goals to the sustainable development goals. Denv. J. Int'l L. \& Pol'y 44:389.

Nayyar, D. 2011. 'The MDGs after 2015: Some reflections on the possibilities,' UN System Task Team on the Post-2015 UN Development Agenda.
Newman, P. 2008. 'The contribution of religion to social inclusion: The role of the Jewish Christian Moslem Association. Partnerships for Social Inclusion,' Conference, Centre for Public Policy, Melbourne.

Okonta, P. 2017. Race-based Political Exclusion and Social Subjugation: Racial Gerrymandering as a Badge of Slavery. Colum. Hum. Rts. L. Rev. 49:254.

Onsando, G. 2014. Refugee immigrants: addressing social exclusion by promoting agency in the Australian VET sector, available on https://core.ac.uk/download/pdf/143887356. pdf Accessed on: 16th December 2019.

Osanloo, A. F., Boske, C. \& Newcomb, W. S. 2016. Deconstructing macroaggressions, microaggressions, and structural racism in education: Developing a conceptual model for the intersection of social justice practice and intercultural education. International Journal of Organizational Theory and Development 4:1.

Peace, R. 2001. Social exclusion: A concept in need of definition? Social Policy Journal of New Zealand 16:17.

Robinson, T. L. \& Howard-Hamilton, M. F. 2000. The Convergence Of Race, Ethnicity, and Gender: Multiple Identities in Counseling. Upper Saddle River, N.J: Merrill.

Segger, M. C. C. \& Khalfan, A. 2004. Sustainable Development Law: Principles, Practices, and Prospects. OUP Catalogue.

Segger, M. C. C. \& Weeramantry, C. G. 2005. Sustainable Justice: Reconciling Economic, Social and Environmental Law. Martinus Nijhoff Publishers.

UNDESA \& World Bank Group. 2019. Sustainable Development Goal 10 - Reduced Inequalities: Progress and Prospects An Expert Group Meeting in preparation for HLPF 2019: Empowering people and ensuring inclusiveness and equality, available from, https://sustainabledevelopment. un.org/content/documents/21453SDG_10_EGM_2019 concept_note_30Jan_consolidated.pdf Accessed on: 22nd April 2020.

UN Department of Economic \& Social Affairs. 2016. Leaving No One Behind: The Imperative of Inclusive Development Report on the World Social Situation 2016 https://www. un.org/esa/socdev/rwss/2016/full-report.pdf. Accessed on: 16th December 2019.

UNHR. 2015. Integrating Human Rights into the Post-2015 Development Agenda Follow-up and Review: Ensuring Accountability for the SDGs, available from, https:// www.ohchr.org/Documents/Issues/MDGs/Post2015/ AccountabilityAndThePost2015Aagenda.pdf Accessed on: 15th December 2019.

UN Task Team on the Post-2015 UN Development Agenda. 2012. Review of the Contributions of the MDG Agenda to Foster Development: Lessons for the post-2015 UN Development Agenda, available from, https://www.un.org/ millenniumgoals/pdf/mdg_assessment_Aug.pdf Accessed on: 16th December 2019.

Véras, M. P. B. 2006. URBAN SOCIETY: Social Inequality and Exclusion. Problematizing the Brazilian Cities, available from, https://isocarp.org/app/uploads/2015/02/ Istanbul-2006-_TXT_MAURA-PARDINI-BICUDO-VERAS. pdf Accessed on: 17th December 2019.

Verner, D. \& Alda, E. 2004. Youth at Risk, Social Exclusion, and Intergenerational Poverty Dynamics: A New Survey Instrument with Application to Brazil. The World Bank.

White, M. J., Muhidin, S., Andrzejewski, C., Tagoe, E., Knight, R., \& Reed, H. 2008. Urbanization and fertility: An eventhistory analysis of coastal Ghana. Demography 45:803. 
Wiik, T. K. 2014. Social Exclusion, Urban Poverty and the Vulnerability to Forced Evictions: a Case Study of Kibera, Nairobi available from, https://www.duo.uio.no/bitstream/ handle/10852/41270/Kjendseth-Wiik--Thomas-MA-ThesisPECOS.pdf Accessed on: 17th December 2019.

Wodon, Q., \& Gacitúa-Marió, E. 2011. 'Measurement and Meaning: Combining Quantitative and Qualitative Methods for the Analysis of Poverty and Social Extension in Latin America', World Bank.

Wolff, J. 2017. Forms of differential social inclusion. Social Philosophy and Policy 34:164.

World Meteorological Organization. 2017. Natural hazards and disaster risk reduction, available from, https://public. wmo.int/en/our-mandate/focus-areas/natural-hazards-anddisaster-risk-reduction Accessed on: 17th December 2019.

Wysokińska, Z. 2017. Millenium development goals/UN and sustainable development goals/UN as instruments for realising sustainable development concept in the global economy. Comparative Economic Research 20:101.
Yang, J. 2013. Social exclusion and young rural-urban migrants' integration into a host society in China. The Annals of the American Academy of Political and Social Science 648:52.

Zhong, H., Xu, J., \& Piquero, A. R. 2017. Internal migration, social exclusion, and victimization: An analysis of Chinese rural-to-urban migrants. Journal of Research in Crime and Delinquency 54:479.

Nurul Hidayat Ab Rahman

Faculty of Law

Universiti Kebangsaan Malaysia

43600 Bangi, Selangor

Email: nhidayat@ukm.edu.my

Saidatul Nadia Abd Aziz

Faculty of Law

Universiti Kebangsaan Malaysia

43600 Bangi, Selangor

Email: nadia_aziz@ukm.edu.my 